\title{
Synthesis and X-Ray Structure of New
} Anticancer Nucleosides Based on

\section{1-((2-Hydroxyethoxy)methyl)-5- \\ (phenylthio)-1H-1,2,4-triazole- 3-carboxamide}

\author{
Yulong Lei ${ }^{1}$, Dehua Zhang1*, Yang Liu², Guanghui Tian², Hongguang Ge² \\ ${ }^{1}$ College of Chemistry and Chemical Engineering \& Hubei Key Laboratory of Pollutant Analysis \& Reuse \\ Technology, Hubei Normal University, Huangshi, China \\ ${ }^{2}$ School of Chemistry \& Environmental Science, Shaanxi University of Technology, Hanzhong, China \\ Email: zhangdehua200@163.com
}

Received 17 April 2014; revised 16 May 2014; accepted 16 June 2014

Copyright (C) 2014 by authors and Scientific Research Publishing Inc.

This work is licensed under the Creative Commons Attribution International License (CC BY).

http://creativecommons.org/licenses/by/4.0/

c) (i) Open Access

\section{Abstract}

A pair of new anticancer nucleosides based on 1,2,4-triazole nucleosides and 1-((2-hydroxyethoxy) methyl)-5-(phenylthio)-1H-1,2,4-triazole-3-carboxamide have been synthesized, and have given the corresponding products in excellent yields. Its structures and conformations were confirmed by single crystal $X$-ray diffraction.

\section{Keywords}

Anticancer Nucleosides, Triazole Nucleosides, Excellent Yields

\section{Introduction}

Synthetic nucleoside analogs with modified nucleobase and/or sugar moieties are of considerable importance in the search for promising candidates leads endowed with antiviral, anticancer, and antibacterial activities [1] [2]. Nucleoside analogs with modified sugar and/or base moieties can mimic natural nucleosides and serve as building units or inhibitors that interfere in nucleic acid synthesis or block nucleoside-dependent biological processes.

"Corresponding author.

How to cite this paper: Lei, Y.L., Zhang, D.H., Liu, Y., Tian, G.H. and Ge, H.G. (2014) Synthesis and X-Ray Structure of New Anticancer Nucleosides Based on 1-((2-Hydroxyethoxy)methyl)-5-(phenylthio)-1H-1,2,4-triazole-3-carboxamide. Journal of Crystallization Process and Technology, 4, 135-139. http://dx.doi.org/10.4236/jcpt.2014.43017 
Well-known nucleoside drugs include the antiviral drugs ribavirin, acyclovir, and zidovudine, and the most commonly used anticancer nucleoside drugs include gemcitabine and cladribine. We have been engaged in a program to develop structurally diverse triazole nucleoside analogs. These nucleosides contain triazole as nucleobase and aromatic groups have been appended on the nucleobases [3] [4], with a view to identifying new structural leads exhibiting biologically interesting activity. Pancreatic cancer is one of the most lethal forms of human cancer, and drug resistance develops extremely fast. The current first-line treatment for pancreatic cancer is based on gemcitabine, which is only moderately effective, with a median survival period of 5 months and a five-year survival rate as low as 3\% [5] [6]. Consequently, there is an urgent need to develop more efficacious drug candidates to treat pancreatic cancer [7].

We report on the synthesis of S-arylated triazole acyclonucleoside analogue, using a simple and efficient Sarylation procedure without catalyst, giving the corresponding products in excellent yields.

The synthesis of the title new anticancer nucleosides 2 is shown in Scheme 1. The structures and conformations of compound 2 were further elucidated by their single crystal X-ray diffraction, as shown in Figure 1. Three-dimensional molecular-packing diagram of the title compound was shown in Figure 2.

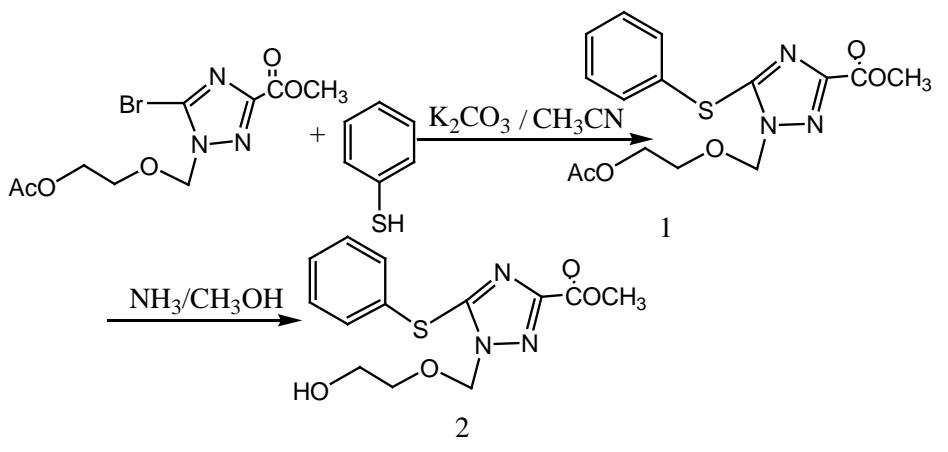

Scheme 1. Synthesis of the anticancer nucleosides intermediate 2.

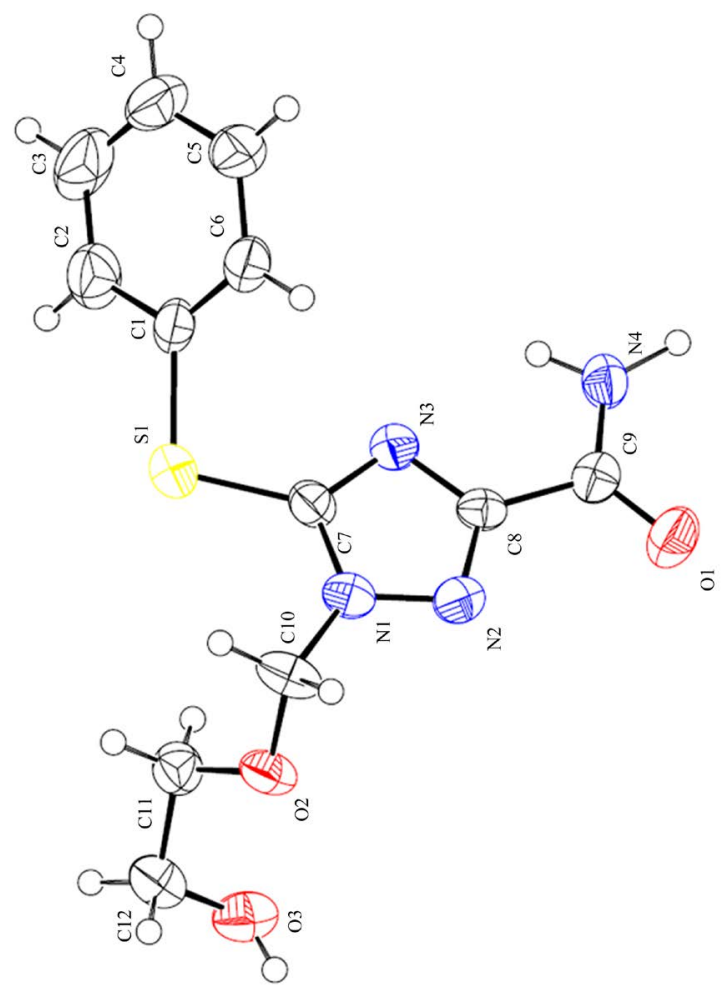

Figure 1. The single crystal structure of compound 2. 


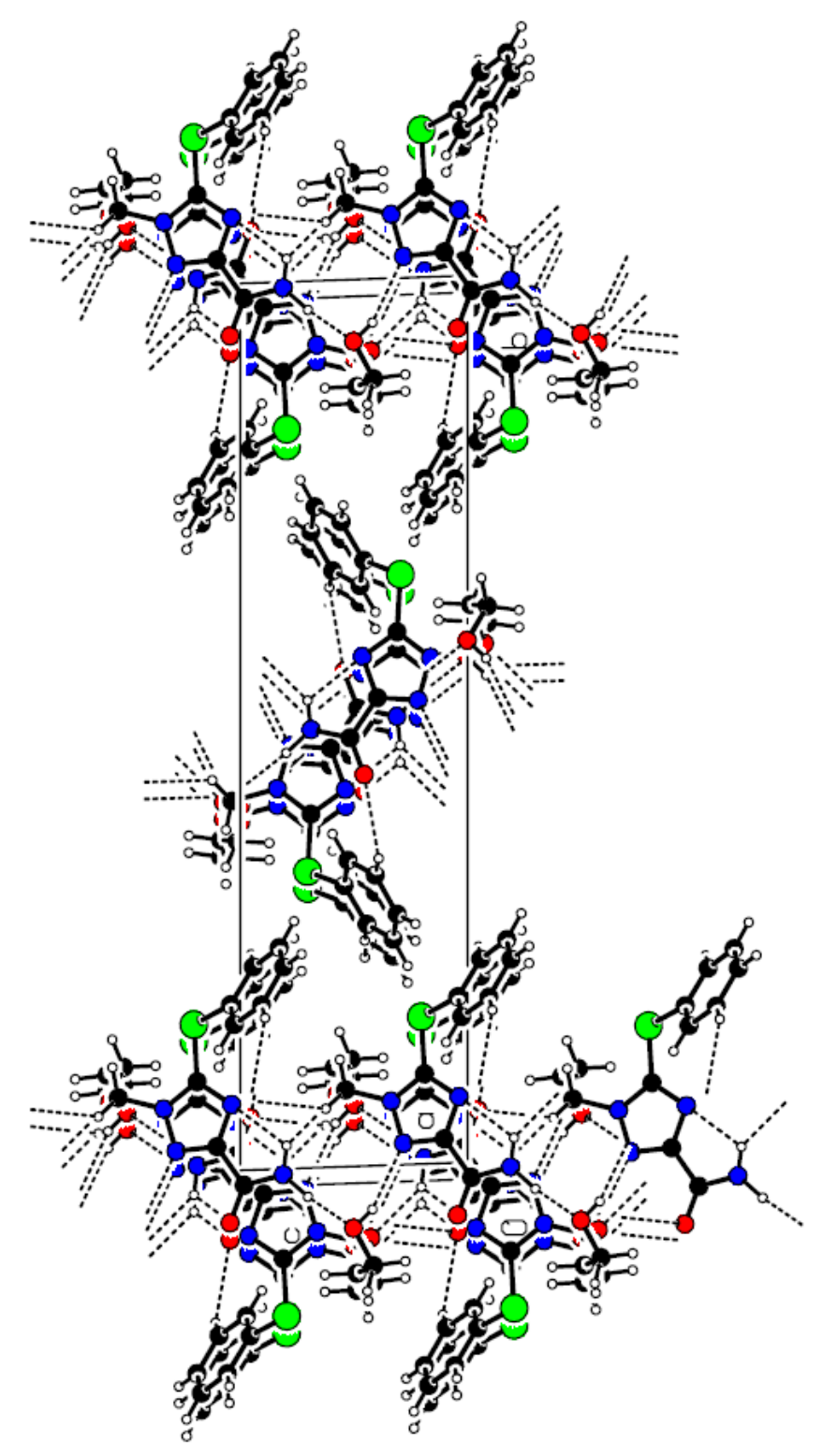

Figure 2. Three-dimensional molecular-packing diagram of the title compound.

The crystals of $\mathbf{2}$ were obtained by slow evaporation of their solution in ethyl acetate/petroleum ether (3:1, v/v) mixtures. The crystal structures of 2 clearly revealed that it has well-defined geometry due to the rigidity that the fused rings confer on the molecule. Its structures and conformations were confirmed by single crystal X-ray diffraction. The dihedral angle between the benzene and the other triazole rings (N2, N1, C7, N3, C8) is 52.94 . The molecular conformation is stabilized by $\mathrm{N}---\mathrm{H} . . . \mathrm{O}$ hydrogen bond. The crystal packing is governed by $\mathrm{C}---\mathrm{H} . . . \mathrm{O}$ and $\mathrm{C}---\mathrm{H} . . . \mathrm{N}$ hydrogen interactions resulting in a three-dimensional network. These values are suitable for the complexation of an aromatic ring by $\pi-\pi$ stacking interactions.

\section{Experimental Details}

\subsection{Preparation of 1 [8]}

Methyl 1-((2-acetoxyethoxy)methyl)-5-bromo-1H-1,2,4-triazole-3-carboxylate (32.2 mg, $0.1 \mathrm{mmol})$, the corresponding 4-benzenethiol $(0.12 \mathrm{mmol})$, and $\mathrm{K}_{2} \mathrm{CO}_{3}(27.6 \mathrm{mg}, 0.2 \mathrm{mmol})$ were suspended in $2 \mathrm{~mL}$ of fresh dis- 
tilled $\mathrm{CH}_{3} \mathrm{CN}$ under argon. The vessel was sealed and the reaction was carried out under microwave irradiation at $100^{\circ} \mathrm{C}$ for $30 \mathrm{~min}$, and then cooled to room temperature. The reaction mixture was concentrated under reduced pressure and the crude residue was purified by flash chromatography on silica gel (petroleum ether/ethyl acetate, 2:1). The purified material was dried in vacuo to afford the corresponding product as colorless oil, an amount of $35.2 \mathrm{mg}$ of compound 2 was obtained with a excellent yield of $99 \%$.

\subsection{Preparation of 2 [9]}

The solution of $\mathrm{NH}_{3} / \mathrm{MeOH}$ (18 mL) was added to a flask contammg compound 1 (90.6 mg, $0.258 \mathrm{mmol}$ ), and the mixture was stirred at room temperature until two days. After removal of the solvent, the compound 4 (63.9 $\mathrm{mg}, 84 \%$ ) was obtained as a white solid.

White crystals suitable for XRD formed after a few days of slow evaporation of the solvent at room temperature over several days. Yellow single crystals of the title compound are shown in Figure 1. The crystal structures of 1 clearly revealed that it has well-defined geometry due to the rigidity that the fused rings confer on the molecule.

\subsection{Characterization}

All reagents obtained from commercial sources were of AR grade. Melting points were determined with XT4A micromelting point apparatus and were uncorrected. The ${ }^{1} \mathrm{H}$ NMR was recorded on a Mercury Plus-400 spectrometer with TMS as internal reference and $\mathrm{CDCl}_{3}$ as solvent. IR were recorded on a Perkin-Elmer PE-983 IR spectrometer as $\mathrm{KBr}$ pellets with absorption in $\mathrm{cm}^{-1}$. MS were obtained with Finnigan Trace MS instrument using EI method. Elemental analyses were carried out on a Vario EL III instrument.

\section{Results and Discussion}

\subsection{Single Crystal X-Ray Diffraction Analysis}

Single crystal X-ray diffraction studies were carried out on the grown crystals. The X-ray date were collected using X-ray diffractometer (Model: Bruker Smart APEX-CCD). A white crystal of the title compound 4 was each mounted on a glass fibre in a random orientation at 298(2) K. The determination of the unit cell and the data collection were performed with MoKa radiation $(\lambda=0.71073 \AA)$ on a Bruker Smart Apex-CCD diffactometer with a $\psi-\omega$ scan mode. The structure was solved by direct methods with SHELXS-97 program and expanded by Fourier technique. The non-hydrogen atoms were refined anisotropically, and the hydrogen atoms were placed at the calculated positions.

Crystal data for 2: $\mathrm{C}_{12} \mathrm{H}_{14} \mathrm{~N}_{3} \mathrm{O}_{4} \mathrm{~S}, \mathrm{M}=294.33$, Triclinic, space group P2(1)/n, a = 7.347(2) $\AA, \mathrm{b}=26.952(7) \AA$, $\mathrm{c}=7.708(2) \AA, \alpha=90^{\circ}, \beta=116.505(5)^{\circ}, \gamma=90^{\circ}, \mathrm{V}=1365.7(6) \AA^{3}, \mathrm{Z}=4, \mathrm{Dc}=1.431 \mathrm{Mg} / \mathrm{m}^{3}$. Reflections collected: 8719 , independent reflections: $2675\left[R_{\text {int }}=0.1147\right.$, Final $\mathrm{R}$ indices $[I>2 \operatorname{sigma}(I)]: \mathrm{R}^{1}=0.0686, \mathrm{wR}^{2}=$ 0.1291 . $\mathrm{R}$ indices (all data): $\mathrm{R}^{1}=0.1183, \mathrm{wR}^{2}=0.1475$.

\subsection{The Structure Characterized}

Compound of 1. ${ }^{1} \mathrm{H}$ NMR (300 MHz, $\left.\mathrm{CDCl}_{3}\right): \delta 7.51-7.54(\mathrm{~m}, 2 \mathrm{H}$, phenyl-H), $7.36-7.38(\mathrm{~m}, 3 \mathrm{H}$, phenyl-H), 5.66 (s, $2 \mathrm{H},-\mathrm{OCH}_{2} \mathrm{~N}-$ ), $4.13\left(\mathrm{t}, 2 \mathrm{H}, J=4.7 \mathrm{~Hz},-\mathrm{OCH}_{2} \mathrm{CH}_{2} \mathrm{OAc}\right), 3.99$ (s, 3H, $\left.-\mathrm{OCH}_{3}\right), 3.76$ (t, $2 \mathrm{H}, J$ $\left.=4.7 \mathrm{~Hz},-\mathrm{OCH}_{2} \mathrm{CH}_{2} \mathrm{OAc}\right), 2.05\left(\mathrm{~s}, 3 \mathrm{H},-\mathrm{C}(\mathrm{O}) \mathrm{CH}_{3}\right) ;{ }^{13} \mathrm{C}$ NMR $\left(150 \mathrm{MHz}, \mathrm{CDCl}_{3}\right): \delta 170.9,159.9,154.6,153.5$, 132.3, 129.8, 129.2, 78.4, 67.9, 62.8, 53.1, 21.0; Maldi-MS: $\mathrm{m} / \mathrm{z} 352.1[\mathrm{M}+\mathrm{H}]^{+}$; HRMS: calcd. for $\mathrm{C}_{15} \mathrm{H}_{18} \mathrm{~N}_{3} \mathrm{O}_{5} \mathrm{~S}^{+} 352.0962$, found 352.0951 .

Compound of 2. ${ }^{1} \mathrm{H}$ NMR (300 MHz, $\mathrm{CDCl}_{3}$ ): $\delta 7.93$ (br s, $\left.1 \mathrm{H},-\mathrm{C}(\mathrm{O}) \mathrm{NH}_{2}\right), 7.70$ (br s, $1 \mathrm{H},-\mathrm{C}(\mathrm{O}) \mathrm{NH}_{2}$ ), 7.39 - 7.51 (m, 5H, phenyl-H), 5.66 (s, 2H, $\left.-\mathrm{OCH}_{2} \mathrm{~N}-\right), 4.74(\mathrm{t}, 1 \mathrm{H}, J=5.4 \mathrm{~Hz},-\mathrm{OH}), 3.51-3.55(\mathrm{~m}, 2 \mathrm{H}$, $-\mathrm{OCH}_{2} \mathrm{CH}_{2} \mathrm{OH}$ ), $3.44-3.47\left(\mathrm{~m}, 2 \mathrm{H},-\mathrm{OCH}_{2} \mathrm{CH}_{2} \mathrm{OH}\right) ;{ }^{13} \mathrm{C}$ NMR (75 MHz, DMSO-d ${ }_{6}$ ): $\delta 160.5,157.7,151.4$, 131.7, 130.9, 130.3, 129.2, 78.7, 71.8, 60.4; Maldi-MS: $\mathrm{m} / \mathrm{z} 295.1[\mathrm{M}+\mathrm{H}]^{+}$; HRMS: calcd. for $\mathrm{C}_{12} \mathrm{H}_{15} \mathrm{~N}_{4} \mathrm{O}_{3} \mathrm{~S}^{+}$ 295.0859, found 295.0853 .

\section{Conclusion}

A pair of new 1-((2-hydroxyethoxy)methyl)-5-(phenylthio)-1H-1,2,4-triazole-3-carboxamide derived from 1,2,4- 
triazole nucleoside have been synthesised. Their structures and conformations were confirmed by single crystal $\mathrm{X}$-ray diffraction and ${ }^{1} \mathrm{H}$ NMR. Both have great potential to bind aromatic guest molecules. Further studies on their binding properties are in progress.

\section{Acknowledgements}

We thank the Hubei provincial Department of Education (Grant No. D20112503), Hubei Key Laboratory of Pollutant Analysis \& Reuse Technology (Grant No. KL2013G06), the Shanxi provincial Department of Education (Grant No. 2013JK0659) and Shanxi University of Technology (SLGQD13-2) for financial support.

\section{References}

[1] Claire, S. (2001) Nucleoside Mimetics: Their Chemistry and Biological Properties (Advanced Chemistry Texts). Gordon and Beach Science, UK.

[2] Herdewijn, P., Ed. (2008) Modified Nucleosides in Biochemistry, Biotechnology and Medicine. Wiley-VCH, Weinheim. http://dx.doi.org/10.1002/9783527623112

[3] Xia, Y., Liu, Y., Wan, J.Q., Wang, M.H., Rocchi, P., Qu, F.Q., Iovanna, J.L. and Peng, L. (2009) Novel Triazole Ribonucleoside Down-Regulates Heat Shock Protein 27 and Induces Potent Anticancer Activity on Drug-Resistant Pancreatic Cancer. Journal of Medicinal Chemistry, 52, 6083-6096. http://dx.doi.org/10.1021/jm900960v

[4] Wan, J.Q., Xia, Y., Liu, Y., Wang, M.H., Rocchi, P., Yao, J.H., Qu, F.Q., Neyts, J., Iovanna, J.L. and Peng, L. (2009) Discovery of Novel Arylethynyltriazole Ribonucleosides with Selective and Effective Antiviral and Antiproliferative Activity. Journal of Medicinal Chemistry, 52, 1144-1155. http://dx.doi.org/10.1021/jm800927r

[5] Rivera, F., López-Tarruella, S., Vega-Villegas, M.E. and Salcedo, M. (2009) Treatment of Advanced Pancreatic Cancer: From Gemcitabine Single Agent to Combinations and Targeted Therapy. Cancer Treatment Review, 35, 335-339. http://dx.doi.org/10.1016/j.ctrv.2008.11.007

[6] Pierantoni, C., Pagliacci, A., Scartozzi, M., Berardi, R., Bianconi, M. and Cascinu, S. (2008) Pancreatic Cancer: Progress in Cancer Therapy. Critical Reviews in Oncology/Hematology, 67, 27-38. http://dx.doi.org/10.1016/j.critrevonc.2008.01.009

[7] Wong, H.H. and Lemoine, N.R. (2009) Pancreatic Cancer: Molecular Pathogenesis and New Therapeutic Targets. Nature Reviews Gastroenterology and Hepatology, 6, 412-422. http://dx.doi.org/10.1038/nrgastro.2009.89

[8] Liu, Y., Xia, Y., Li, W., Maggiani, A., Leyssen, P., Qu, F.Q., Neyts, J. and Peng, L. (2010) S-Aryltriazole Acyclonucleosides: Synthesis and Biological Evaluation against Hepatitis C Virus. Bioorganic \& Medicinal Chemistry Letters, 20, 3610-3613. http://dx.doi.org/10.1016/j.bmcl.2010.04.115

[9] Narik, S.R., Witkowski, J.T. and Robins, R.K. (1974) Synthesis of Nucleosides of 5-Substituted-1,2,4-triazole-3-carboxamides. Journal of Heterocyclic Chemistry, 11, 57-61. http://dx.doi.org/10.1002/jhet.5570110112 
Scientific Research Publishing (SCIRP) is one of the largest Open Access journal publishers. It is currently publishing more than 200 open access, online, peer-reviewed journals covering a wide range of academic disciplines. SCIRP serves the worldwide academic communities and contributes to the progress and application of science with its publication.

Other selected journals from SCIRP are listed as below. Submit your manuscript to us via either submit@scirp.org or Online Submission Portal.
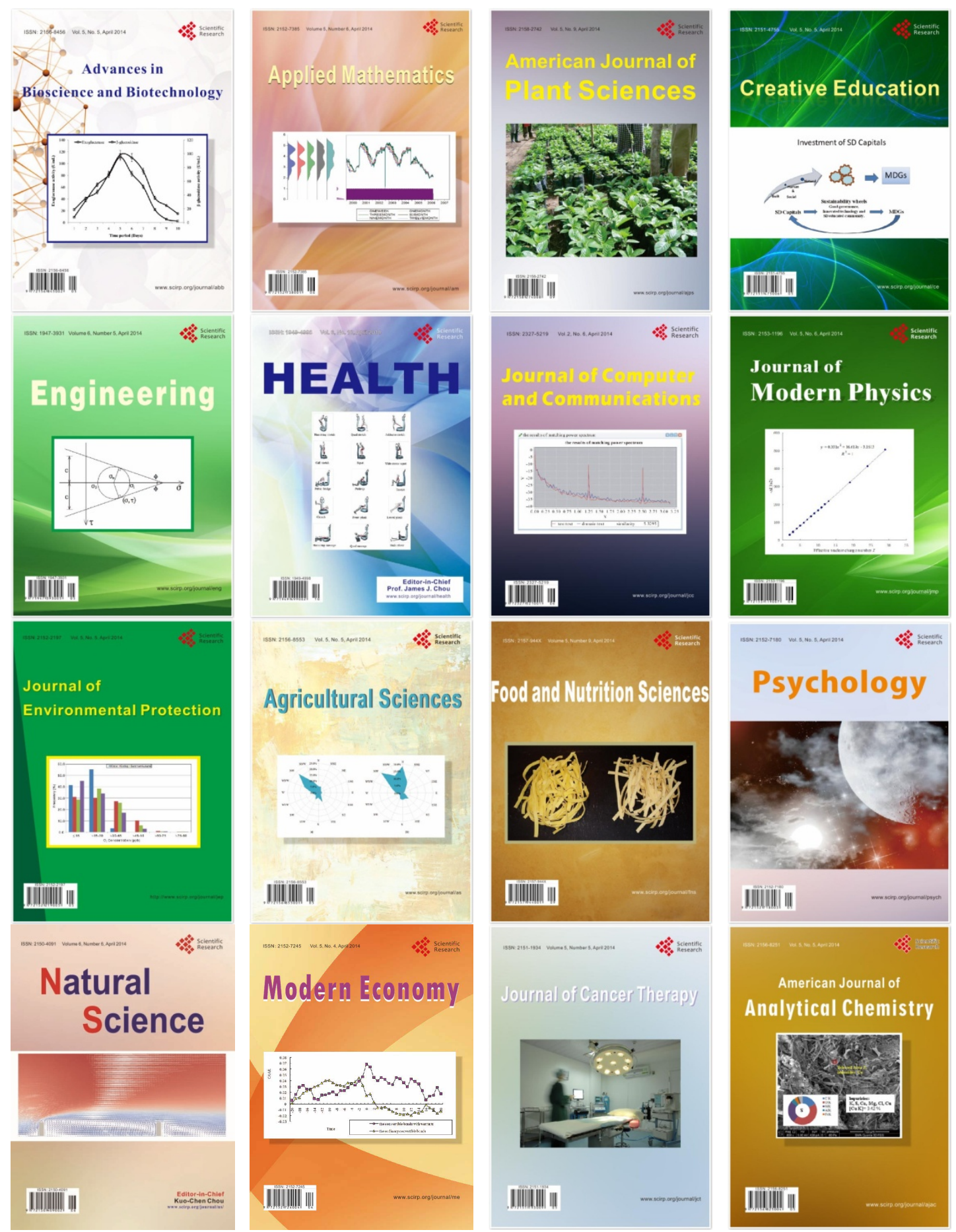